\title{
Corrigendum: Outcome-oriented moral evaluation in terrorists
}

Sandra Baez, Eduar Herrera, Adolfo M. García, Facundo Manes, Liane Young and Agustín Ibáñez

Nature Human Behaviour 1, 0118 (2017); published 26 May 2017; corrected 24 July 2017.

In the version of the Letter originally published, in the sentence beginning 'International Amnesty ${ }^{9}$ estimates that...' and in ref. 9, 'International Amnesty' should have read 'Amnesty International'. This has now been corrected in all versions of the Letter. 